\title{
THE USE OF SEMANTIC MAPPING TO INCREASE STUDENTS VOCABULARY AT THE SECOND GRADE STUDENTS OF SMPN 9 MATARAM IN ACADEMIC YEAR 2014/2015
}

\author{
${ }^{1}$ HIDAYATI, ${ }^{2}$ RUSNAINI \\ ${ }^{1}$ Dosen Program Studi Pendidikan Bahasa Inggris, Universitas Muhammadiyah Mataram \\ ${ }^{2}$ Alumni Program Studi Pendidikan Bahasa Inggris, Universitas Muhammadiyah Mataram \\ Email : hidayatiumm@yahoo.com
}

\begin{abstract}
Semantic mapping is introduced as a vocabulary presentation technique. The purpose of this research is to know the effectiveness of using semantic mapping in developing students' vocabulary to the second year students' of SMPN 9 Mataram in Academic year 2014/2015. The population of the study was the second year students of SMPN 9 Mataram, there are six classes and every class consist of 26 students', so, the total number of the population were 180 students, and the researcher only took one class is VIII A, with consist of 26 students. This study is kind of pre-experimental in research designed pretest-posttest group, using a measurement technique in form of multiple choices and semantic mapping which consist of 30 test items. Based on the data analysis the mean score of pre-test 39, qualifying "POOR" and mean score ofposttest88 qualifying average to "GOOD", and the result of t-test that is 45,6. Based on the distribution t-table with $\mathrm{db}=26$, the research showed the distribution t-table was $99 \%$ trust interval and level of significant $1 \%$. And the result confirmed that the using of semantic mapping technique in teaching vocabulary at the eight class students is effective in increasing student's vocabulary mastery.
\end{abstract}

Key words: Semantic Mapping, Vocabulary

\section{INTRODUCTION}

Teaching vocabulary is one way to improve the students knowledge to be able to build a grammatical sentence and teaching vocabulary also is one of the difficult items complemented by teacher because of many things should be concerned to make student can understand what is the vocabulary itself. Nguyen and Khuat (2003), also greed that vocabulary knowledge plays an important role in learning a foreign language, Vocabulary is one element that links the four skills of speaking, listening, reading and writing all together. Vocabulary is a core component of language proficiency and provides much of the basis for how well learners listen, speak, read, and write (Richards and Renandya, 2002).

In fact, vocabulary is a means to support communication. It is a necessary component of language instruction. In order to communicate well in a foreign language, learners should acquire an adequate numbers of words and should know how to use them accurately. When emphasizing the importance of vocabulary in communication, Della and Hocking (1992) also a little grammar, the learners only have a little smooth communication. Without vocabulary, it is difficult for others to understand the information of the speakers' expression. For this reason, a lack of good grammatical structures may not interrupt communication.

Some problem caused by the method that used in the class. The teacher did no present the material in interesting way or used an interesting technique when teaching learning process. It makes the students get bored. Based on the research observation done by researcher when doing PPL (praktek pengalaman lapangan) in SMPN 9 Mataram, especially in the eighth grade students, it shown that the teacher explained the material in front of class without using interesting technique. The teacher usually directly explained the material by giving some examples and asked some questions.

In teaching vocabulary, various techniques need to be used in order to motivate the learners to enjoy the English class and to avoid them from getting bored; the researcher assumes that the use of semantic mapping, learning process in teaching vocabulary could be productive and beneficial to increase the students' mastery of vocabulary easily. The use of semantic mapping is expected to motivate the students to learn and make them not get bored in English teaching learning process.

Semantic mapping is a term, which describes a variety of strategy designed to show how key word or concepts are related to one another through graphic representations. Semantic mapping can be defined as a visual representation of knowledge, as picture of conceptual relationship, Barcroft (2004:200) defines semantic mapping as "the increased evaluation of an item with regard to its meaning". A semantic map can be used as a tool for discovering the conceptual relationships between vocabulary items. Semantic elaboration seems to enhance word learning and 
retention, through a learning phase called 'integration' (Shostak,2003).

Integration is based on the view that in order for learning to occur, new information should be incorporated into what the learner previously knows (Christen and Murphy, 1991, cited in Shostak, 2003). That is, instruction should guide learners to use words and ideas available to them in their word and concept repertoire to help them associate meaning with words they do not know.

It is believed that this will lead to deeper learning, and thus, longer retention of the learned words. Previous research on vocabulary acquisition has revealed a significant improvement in vocabulary learning whenever semantic maps were employed.

Beside that this technique is over period of time that student would be acquire not only vocabulary, but also the way in which concept of language can be expressed. Moreover semantic mapping could be beneficial for the students to learn English directly. It is considered from the point of view of comprehension and student would get constant exposure to how important concepts are expressed. This technique emphasizes comprehension by using the connections among word informs a map, the student more easily to remember word better as they in a map, because semantic mapping is as a good vocabulary presentation technique. Morinand Goebel (2001) cited in sasan (2011) state that semantic mapping as a strategy that helps the learner recall word better.

Based on the reason above, the researcher is interested in doing this research entitled 'The Use of Semantic Mapping in Developing Student's Vocabulary. The vocabulary development focuses on helping students teach the meaning of new words and concepts .Helping the students to develop vocabulary means providing explicit instruction on important words from reading passages and technique to help them learn word meaning independently in SMPN 9 Mataram.

Based on the introduction of the problems above, the researcher would like to present the objectives of the research as follow:"The rationale of this study is to know the effectiveness of using semantic mapping in increasing the students' vocabulary at the second grade of SMPN 9 Mataram in academic year 2014/2015".

\section{REVIEW OF RELATED LITERATURE \\ A. An Overview about Vocabulary}

Vocabulary is broadly defined as knowledge of words and word meanings (Lehr et al., 2004). According to Lehr and his colleagues, vocabulary is more complex than this definition suggests. First, words come not only in oral forms including those words that can be recognized and used in listening and speaking but also in print forms to be recognized and used in reading and writing. Second, word knowledge also comes in two forms: receptive and productive. Receptive vocabulary is words that can be recognized in reading and listening. Productive vocabulary refers to words that can be used in speaking and writing (Lehr ET.Al., 2004). Therefore, vocabulary is understood as knowledge of word spelling, pronunciation,

Collocations (i.e.Words it co-occurs with), and appropriateness (Nation,1990). However, Pyles (1970) confirmed that vocabulary is the focus of language with its sounds and meaning, which interlock to allow us to communicate with one another.

As discussed above, vocabulary can be seen in many different ways. Vocabulary refers to words or a set of words in a language or knowledge of words regarding its form, meaning and how to use it accurately in the context. In the present study, vocabulary refers to the words, compounds and idioms in a language that can be used to conveyed and received information in oral and written communication.

\section{B. Vocabulary as a Language Component}

Vocabulary in any language plays very important role in communication activities. English vocabulary is one of the important elements of the language to be mastered by English or other language learner to communicate in the language. We cannot understand what other people say if we have no vocabulary about the language and it can be a problem for expressing our mind if we lack of vocabulary. Knowledge of vocabulary is an important part and one of the language basics elements. Knowledge of vocabulary also involves using the word to stand for meaning, it represent and being able to think of suitable substitutes for the word if there any. In relation on the second language learning, vocabulary learning affected by first learner's previous experience with the mother tongue. Second, the learning burden of word can be affected by the way it is thought. Last difficulty of words lies on the intrinsic difficulty.

\section{Teaching of Vocabulary}

Advance language learner can generally communicate well, after they have learnt all the basic structures of language. However they need to broaden their vocabulary to express themselves more clearly and appropriately in a wide range of situation. Traditionally, the teaching of vocabulary level was mostly incidental limit to presenting new item as they appeared in reading or sometime listening text. This in direct teaching of vocabulary assume that vocabulary expansion will happen through the practice of other language skill, which have been proved not enough to ensure vocabulary expansion. Nowadays it is widely accepted that vocabulary teaching should be part of syllabus, and thought in a well -planned and 
regular basic. Lewis in Solange (2001) argues that vocabulary should be at centre of language teaching because languages consist of grammatical lexis, not lexicalized grammar.

\section{Technique for Teaching Vocabulary}

There are some techniques for teaching vocabulary at any level students, namely:

1. Vocabulary Technique

There are two main approaches to the teaching vocabulary. First; the list approach gives list of word and their meaning. The second main is list of words may or may not be related to the topic realize on students ascertaining the meaning of words through reading, and related activities.

2. Semantic Mapping

Write a word on the board and have the students to brainstorming the words that they think are relate to the word topic. After the students finish brainstorming the words, group the words into categories and give each category a label. After the categories are labelled, give the students an opportunity to add the list. Allow the students to continue to add to the lesson or unit involves.

3. Sesquipedalian Word

Sequa is from Latin meaning one and onehalf. Pad means foot. Sesquipedalian means "foot and a half" or very long words, step ups bulletin board and allow children to add words to the board. They should use the word in a sentence. Allow other students to guess the meaning.

Supply a list of related words. Have students short the words into categories. The sort can be open (the student create their own categories and label them) or it can be close (the teacher supplies the categories). After sorting, the student discuss why the sorted them the way they did Gunning.

\section{E. Semantic Mapping Technique}

Semantic mapping is a visual technique for vocabulary expansions and extension of knowledge by this playing in categories word related to one another, semantic mapping is an adoption of concept definition mapping and build based on student's prior knowledge. Semantic mapping is one of the most powerful approaches to teaching vocabulary because it engages students in thinking about word relationship (Graves, 2008). While it draws on prior knowledge in recognizes important components and shows the relationship among the component. The framework of semantic mapping includes: the concept word, two categories examples, and other example. This is a very interactive process and should be modelled by the teacher first. They define semantic mapping technique as being "used to motivated and involve students in the way of the thinking. Reading and writing it enhances vocabulary development by helping students to ling the new information with previous experience". The instructional sequence of semantic mapping is as fallow:

1. Select a word central to the topic

For the first step we have to decide that what topic that the class focus on as their topic central.

2. Display the target word after having word topic the students should fine the target word as many words that they can.

3. Invite the students to generate as many words as possible that related to the target words.

4. Have the students to write generation word in categoriesthe students try to relate the words.

5. Have the students label categories after having generated words into categories the students ask to label the categories of the word.

6. Form this list, construct a map the students list the word then construct a map as their semantic map.

7. Lead the class in a discussion that focuses on identifying meaning an use of word, clarifying ideas, highlighting major conclusion, identifying key elements, expending ideas and summarizing information (Mory and Mory in Abdullah Ziad, 2001). Moreover, (Gaut, 2002) define semantic mapping as a teaching that can be used in all disciples to demonstrate the relationship between ideas. When teaching vocabulary explicitly. It can be used as tool for students to discover the relationship between vocabulary words. As semantic mapping build on prior knowledge and it is an active form of learning, it can be a very affective teaching tool.

In addition, Gaut (2002) gave example which showed the greats of semantic mapping technique "perhaps the students to fully grasp the meaning of the word "oyster." (the choice of word will depend on great level, as might be expected) while most students will have a vague notion what on oyster is an less they encounter then regularly in their lives, the image associated with that word will remain vague, and will ultimately affect reading comprehension when the read passage containing that word. Sometimes, their ideas may be influenced by the media, and may be quite narrow. Semantic mapping will broaden the student's personal meaning of the word, and teaching other concepts surrounding it, as well as additional vocabulary in many cases. The teacher will model how to do semantic mapping with the entire class, using the word, and then how the class create 
their own map, either by branching of the original concept, or using related ones.

\section{F. Previous Studies}

Research on semantic mapping has been extensively conducted. Most of the studies focus on using semantic mapping as pre-activities for reading, speaking or writing lessons. The subjects of these studies are often intermediate learners. The results have shown the significant difference in vocabulary learning. Learners using semantic mapping could organize words systematically and recall word meanings easily.

The first research, researchers compared the effectiveness of semantic mapping with of other techniques. Pikula (1987) compared the effectiveness of the two techniques (semantic mapping and dictionary) for 38 students of experimental and control groups. In his research, the experiment group developed the network of semantic categories using their existing knowledge of vocabulary whereas the control group used a dictionary to learn vocabulary. Posttest results at the end of the six-week period indicated statistically significant difference between the two groups. The experimental group exhibited a great enough gain over the control sample.

The second research, DeCarrico (2001) also conducted a research on semantic mapping. She made a decision that semantic mapping is an activity that helps bring into consciousness relationships among words in a text and helps deepen understanding by creating associative networks for words. A text is chosen based in the words to be learnt and students are asked to draw a diagram of the relationship between particular words found in the text. A variation on this technique, a "vocabulary network" could be designed to help even beginning students learn to make semantic associations within a particular super ordinate heading. She concluded that "especially at the beginning levels the teaching of words lists through words association techniques has proven to be successful way to learn a large number of words in a short period and retain them over time".

The third by Nazarudin (2011) on the teaching English vocabular trough semantic mapping. The subject of the study is the use of semantic mapping in developing students vocabulary mastery for the tenth grade of SMAN I Sakratimur in the school year 2011/2012, the problem is to know what extent is the effectiveness of semantic mapping in teaching English vocabulary. The study is aimed to discover the effectiveness of semantic in teaching English vocabulary. The researcher uses test as the instrument in observing of data collection. Then 40 students are taken as the sample from all he eight grade students. He uses descriptive statistic research as a method to analyze data. The result of the study that the tenth grade of SMAN 1 SakraTimur in the school year 2011/2012 and students' achievement in mastering English vocabulary in control group is less then experimental group.

In research mentioned above, there are contrasting points of view. Most of the research notice able that more studies needs to be conducted to test the semantic mapping's effectiveness on junior high school students who are at pre-intermediate level of English proficiency. Besides, there was not yet any empirical study on the use of semantic mapping in vocabulary teaching and learning in the researcher's context. For this reason, the researcher conducted this study to gain more insights into the addressed matter in her context.

\section{RESEARCH METHOD}

The researcher conducts the study with the aim to use of semantic mapping in developing students' vocabulary. This study is kind of pre-experimental in research designed pre test-post test group. In the research design the observation done in 2 times before experiment and after experiment.

The pattern as follow:

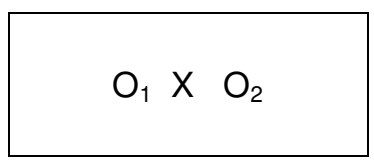

where: $O_{1} \quad=$ The pre-test (before experiment)

$\mathrm{X}=$ The treatment

$\mathrm{O}_{2} \quad=$ The post-test (after experiment)

The difference between $o_{1}$ and $o_{2}$ namely $o_{2}$ $0_{1}$ assumed is effect of treatment or experiment (Arikunto, S, 2010).

There is no control in a this research design, so, the researcher can only comparing the students' scores at the beginning of the class with students score at the end of the class.

\section{A. Population and Sample}

In this research, the population is the second year students of SMPN 9 Mataram, there were six classes and every class consist of 26 students, so, the total number of the population are 180 students.

Sample is part of population, furthermore, if the population less than hundred, it must be taken all as sample, it categorized as population research. However, if population is a hundred and more, it should be taken $10-15 \%$ from all the 
population(Arikunto, S: 2006). Since the second year students of SMPN 9 Mataramconsist of six classes and researcher only taking one class is VIII A, with consist of 26students. The researcher applied purposive sampling.It is because the students at class VIII A are easier to control and they are very cooperative.

\section{B. Data Collection Procedure}

1. Pre-test

Prior to the treatment, students were given a pre-test to test the vocabulary knowledge. The word topics tested were taken from their material. The first think research do in pre-test is distributing some concept word from semantic mapping that the student worked on. In each word concept the student's brains formed and phrase five that they associate with the concept word. Secondly, the researcher will be provided some general clues which can help them to find that word. Each for the correct answer was I point the researcher use five words that is: 'supermarket", beach", class room", post office", house.

\section{Treatments}

The treatment was is form of semantic mapping technique for experimental group but not for control group. The implementation of developing students by using semantic mapping technique was plan $2 \times 45$ minute in duration for teaching. The experimental group was learning vocabulary by using semantic mapping technique, while the control groups was learning vocabulary with semantic mapping technique but the writer provided for them handouts of wordlist of forget vocabularies the treatment was given by the researcher six time before Post-test.

The semantic mapping technique involves three activities:

1. Pre Technique Activities

In the pre teaching activity the researcher told the student about the background and the advantages of studying vocabulary by using semantic mapping technique.

2. Main Technique Activity In main teaching activities the researcher did some list of activities those are:

a. The researcher distributed a word central to the topic which when from the reading material of their lesson.

b. Display the forget word

3. Invite the students to generate as many words as possible that relate to the forget word.

\section{Post-test}

a. Have the students to write generate word is categories.

b. Have students label categories.

c. From this list the students asked to construct a map.

In the end after giving the treatment, the writer will conduct a post test to the experimental group and control group. It will conduct by the aim to know the use of semantic mapping in developing the student's vocabulary. The test is same as the one is given in pre-test.

\section{Method of Data Analysis}

To analysis the data obtained, the researcher usedt-test formula. The t-test assess is whether the means of one group were statistically different from each other. This analysis was operated in comparing the mean of one group.Finally, the researcher analyzed the results of experiments that used a pre-test and post-test one group design (design 2) then the formula is:

where:

$$
t=\frac{M d}{\sqrt{\frac{\sum x^{2} d}{N(N-1)}}}
$$

Md = Themean from difference pre-test with post test (post test-pre test)

$\mathrm{Xd} \quad=$ Deviation of each subject $(\mathrm{d}-\mathrm{Md})$

$\sum X^{2} d=$ Sum of squared deviations

$N \quad=$ Subjects in the sample

d.b = Determined by N-1 (Arikunto, S, 2010).

\section{FINDINGS AND DISSCUSION}

After the researcher finished the field by using semantic mapping method, the researcher used statistic calculation by used t-test.

The formula to account the pre tests and post test scores is given by score pre-test and post-test

$$
=\frac{\text { correct answer }}{\text { Total number of items }} \times 100
$$

The results are tabulated as follows: 
Table 1. Tabulation of pre-test and post-test score of Experimental

\begin{tabular}{|c|c|c|c|c|c|}
\hline No. & Name & $\begin{array}{l}\text { PRE- } \\
\text { TEST } \\
\text { SCORE }\end{array}$ & $\begin{array}{l}\text { POST-TEST } \\
\text { SCORE }\end{array}$ & $\begin{array}{l}\text { Gain (d) } \\
\text { (post-test } \\
\text { pre-test) }\end{array}$ & $x^{2} d$ \\
\hline 1 & AS & 50 & 51 & 1 & 2601 \\
\hline 2 & AY & 59 & 60 & 1 & 3600 \\
\hline 3 & BPS & 45 & 46 & 1 & 2116 \\
\hline 4 & DA & 58 & 60 & 2 & 3600 \\
\hline 5 & EDR & 70 & 71 & 1 & 5041 \\
\hline 6 & FI & 56 & 60 & 4 & 3600 \\
\hline 7 & HA & 56 & 57 & 1 & 3249 \\
\hline 8 & IGAP & 50 & 52 & 2 & 2704 \\
\hline 9 & I NAH & 39 & 42 & 3 & 1764 \\
\hline 10 & IAMRS & 53 & 55 & 2 & 3025 \\
\hline 11 & IA & 80 & 82 & 2 & 6724 \\
\hline 12 & LR & 80 & 81 & 1 & 6561 \\
\hline 13 & MNI & 78 & 80 & 2 & 6400 \\
\hline 14 & $\mathbf{M H}$ & 59 & 62 & 3 & 3844 \\
\hline 15 & MIR & 75 & 77 & 2 & 5929 \\
\hline 16 & MY & 39 & 42 & 1 & 1764 \\
\hline 17 & NDU & 42 & 44 & 2 & 1936 \\
\hline 18 & NIB & 61 & 63 & 2 & 3969 \\
\hline 19 & NNMR & 46 & 50 & 4 & 2500 \\
\hline 20 & NNPS & 58 & 60 & 2 & 3600 \\
\hline 21 & NPAS & 75 & 78 & 1 & 6084 \\
\hline 22 & NWASK & 54 & 56 & 2 & 3136 \\
\hline 23 & PKATSST & 42 & 43 & 1 & 1849 \\
\hline 24 & UN & 85 & 88 & 3 & 7744 \\
\hline 25 & VAS & 63 & 65 & 2 & 4225 \\
\hline \multirow[t]{2}{*}{26} & ZR & 70 & 74 & 4 & 5476 \\
\hline & $\mathrm{N}=26$ & $\begin{array}{c}1543 \\
X_{1}=57,5\end{array}$ & $\begin{array}{c}1599 \\
X_{2}=62,4\end{array}$ & $\sum d=52$ & $\begin{array}{l}\sum x^{2} d= \\
10.3041\end{array}$ \\
\hline
\end{tabular}

From the data in table, it can be seen that the lowest pretest score 39 by Muhamadyandi, I Nengahagushendra. For the highest pre test score 85 byUminurmala. Next the lowest posttest score 42 by Muhamadyandi .and the highest posttestscore 88 by Uminurmala. Based on the result the student's score of pre-test is classified into "poor" category and score of post-test is classified into "average to good" category

\section{A. Data Calculation}

After distributing the pre-test and post-test score.The computation result showed that the mean deviation of the effectiveness of treatment was lower. It means that the result was indicated the independent variable (semantic mapping) gave affect to the dependent variable (developing 
student's vocabulary). After seeing the different score between the two groups, the researcher decided to calculate the data by using T-test value.

Based on the data above, the value of T-test could be given by:

$$
\begin{aligned}
& \mathrm{Md}=\frac{\sum \mathrm{d}}{\mathrm{N}}=\frac{123}{26}=4.88 \\
& t=\frac{M d}{\sqrt{\frac{\sum x^{2} d}{N(N-1)}}} \\
& t=\frac{4.88}{\sqrt{\frac{11.0416}{N(26-25)}}}
\end{aligned}
$$

$\mathrm{t}=45,6$

So, the result from T-test in data calculation is 45,6 .

\section{B. Discussion}

The research find out significant different of the students' vocabulary mastery before and after being tough using semantic mapping. It can be seen from the result of t-test that is 45,6 . Based on the distribution t-table with $\mathrm{db}=26$, the research showed the distribution t-table was $99 \%$ trust interval and level of significant $1 \%$. From the explanation above, the research concludes that there is any significant difference of the student' vocabulary before and after treatment because result of the t-test shows that is 45,6. The alternative hypothesis said that "teaching vocabulary using semantic mapping to the second grade students of SMPN 9 Mataram is effective is accepted"

In the pre-test many mistakes made by the students such as:

1. The students cannot differentiate detail categories of topic support in semantic mapping

2. There is the students mistakes way of writing in detail categories

3. Many students cannot understand what the meaning in question in multiple choice tests.

In the pre-test also students tend to make mistakes when working on semantic maps, they are confused how to do it and do not know what it means, others do not match the desired answer, the answer is supposed to number one in the input in answer number two, and so on.

The last give the post test by using test which is same as pre-test. And after give post-test the researcher give questionnaires to student, where the student's can the learning process semantic mapping, learnt how to use. From the result, the researcher get the result 99\% from students answer yes, because learnt by using semantic mapping technique can develop student's vocabulary, and can make students Paedagoria, September 2016, ISSN 2086-6356 easier to learn the vocabulary, and the students said, with the learn by using semantic mapping, it makes the students easier to remember the vocabulary. And then students are fun so learn by using semantic mapping because it is not difficult for the students.

\section{v. CONCLUSION}

Referring to the research findings and the analysis of the students' test result, the researcher draws the conclusion as three parts. The first using semantic mapping in developing student's vocabulary at the second year students in SMPN 9 Mataramis effective. It can increase their score of test. With result the t-test. With result the t-test $(45,6)$.It means effect of treatment is "high". Second the use of semantic mapping contributed significant change of their score to the second year students' post-test result $(8,8)$ which was higher than the result of students' pre-test $(8,5)$. As a result, the classification of the students mean score turned from poor to average to good criterion. The last, the significant difference of this achievement could also be proved by the t-test $(45,6)$ is bigger that Critical ChiKuadrat. It means that semantic mapping increase the student's vocabulary. And this research proved that using semantic mapping as the teaching technique can develop the vocabulary especially to the second grade students of SMPN 9 Mataram. Furthermore, this kind of technique had been created a good atmosphere or good situation in teaching learning process.

\section{BIBLIOGRAPHY}

Adger. C. T. (2002). What Teacher Need to Know about Language. McHenry,IL, Center For AppliedLinguistic.https://www.google.co.id/(2002 Lwhat teacher need to knowabout language, accessed march 28,2014 13:12:06 GMT

Arikunto, (2010).ProsedurPenelitianSuatuPendekatanPra ktik. Jakarta : PT RinekaCipta.

Arikunto, (2006). ProsedurPenelitianSuatuPendekatanPra ktik. Jakarta : PT RinekaCipta.

Barcroft.J. (2004). Second Language Vocabulary Acquisition: A Lexical Input Processing Approach. Foreign Language Annals. 37, 2, 200 -208.https://www.google.co.id/ (2004).vocabulary acquisition, accessed march 28,2014 09:15:10 GMT

Cohen,L.,Manion, (2000). Research Method and Education.Master e-book.ISBN, ISBN- 0-20322434-5. https://www.google.co.id/ (2000). Research method and education, accessed march 28,2014 09:15:10 GMT

Della, H, \& Hocking, D. (1992). Innovation/ Innovations. Teacher's- books, Vernal :Language Teaching Publications.https://www.google.co.id/ (1992).

Vol. 14, No. 2 
language education, accessed march 28,2014 12:30:11 GMT

Decarirco, j.S. (2001).Vocabulary Learning and Teaching.In Celce- Murcia. M. Teaching English as Second or Foreign Language $\left(3^{\text {rd }}\right.$ adition).Boston MA: Heinle and Heinle. http://google.co.id 2001 about vocabulary learning and teaching, accessed march 28,2014 09:15:10 GMT

Elyansyah.Syarif. (2007). A THESIS: Teaching Vocabulary by Using Pictures.

Pontianak:FKIPUNTAN.http://asian-efl-

journal.com/quarterly-

journal/2007/08/12/lteaching

vocabulary.accessed march 25,2014 11:23:05 GMT

Gaut, Michella. 2002. Teacher: How to Use Semantic Mapping to Increase Vocabulary. http://lala.esortment.com/teachersusemtvej.htm. accessed march 21,2014 18:48:15 GMT

Gunning, Thomas, (2003). Technique for Teaching Vocabulary. Creating Laterally Instruction for All Children.

gunninghttp://www.questian.com/library/journal/1 P3-1367220481/developing-reading-skills-forthe-workplace-a-task/ accessed march 21,2014 19:20:29 GMT

Harvey, S. \&Goudvis, A. (2000) Strategies that Work Teaching Comprehension to Enhance Understanding. New York. ME: Tea House Publisher. http://scholar.google.co.id. Harvey,2000 about semantic mapping, accessed march 20,2014 20:11:03 GMT)

Lehr, et al. (2004). Research-Based Practices in Early Reading Series : A Focus on Vocabulary. Pacific Resources for education and learning. Retrieved on January 20, 2010 from http://www.prel.org/products/re/ES0419.htmacce ssed march 21,2014 18:32:02 GMT

Liu,R. (2004). The Value of Semantic Mapping in Vocabulary Instruction. Term Project: University of Quebec, http://scholar.google.co.id/ gardener about vocabulary, accessed march 21,2014 19:50:16 GMT

Nguyen,T.T.H,. \&Khuat,T. T. N. (2003). The Effectiveness of Learning Vocabulary Through Games. Asian EFL journal Quarterly, 5 (4). Retrieved on January 15, 2010 from http://www.asian-efl-journal.com/dec 03 vn.pdf accessed march 20,2014 19:50:24 GMT .

Nation, P, (1990). Teaching and Learning Vocabulary.Boston:

Heinle\&Heinle.http://www3.telus.net/linguistic sissues/teaching.vocabulary.html, accessed march 21,2014 21:07:02 GMT .

Nazarudin. 2011.A THESIS: The Effectiveness Of Semantic Mapping to Teach Vocabulary Viewed From Student Creativity An Experimental Study
At The Eight Graders Of SMAN 1 SakraTimur In The Academic Year of 2010/2011. Surakarta: Unpublished.http://.google.co.id.(20011) about thesis an experimental study, accessed march 20,2014 21:23:15 GMT)

Pyles, Thomas (1970). English: An Introduction to language. Harcourt College Pub.http://asian-efljournal.com/quarterly-

journal/2003/12/31/learning-vocabulary-throughgames-the-effectiveness-of-learning-vocabularythrough-games, accessed march 20,2014 19:12:06 GMT .

Pikula.J .(1987). The Effect of Semantic Mapping on Vocabulary Growth in Grade four.ERIC:ED284178, http://geogle.co.id. (2008). Effects on vocabulary acquisition of presenting.accessed march 20, 2014 20:12:50 GMT .

Richards,J.C. \&Renandya, W.A. (2002). Strategy in Vocabulary Teaching and Learning Cambridge University Press.http://scholar.google.co.id.2002 strategy in vocabulary, accessed march 24, 2014 14:08:54 GMT .

Shostak, J. (2003). The Value of Direct and Systematic Vocabulary Instruction.Sadlier -Oxford Professional Development Saries, 7,1-11. K, http://scholar.google.co.idshostak 2003 about semantic mapping, accessed march 22,2014 17:45:31 GMT)

Sasan, B. Naeim. (2011). Enhancing Vocabulary Retention Trough Semantic Mapping: Foreign Language Annals. Language Society \& Culture.Journal.http://scholar.google.co.id.sasan 2011 about semantic mapping accessed march 22,2014 17:23:18 GMT

Solange.(2001).Teaching of Vocabulary. http://scholar.google.co.id/solange 2001 about teaching vocabulary.accessed march 29,2014 14:20:13 GMT

Tailor , L.(1990). Teaching and Learning Vocabulary.Herevordshire, UK: Prantice Hall International.

http://scholar.google.co.id/tailor, 1990 about teaching learning vocabulary, accessed march 24,2014 10:11:20 GMT 